\title{
Functional and Nutritional Characteristics of Organic Jaggery Millet Cookies
}

\author{
B.K. Mahalaxmi* and S. Hemalatha \\ Department of Food Science and Nutrition, College of Rural Home Science \\ University of Agricultural Sciences, Dharwad 580005 Karnataka, India \\ *Corresponding author
}

\section{Keywords}

Jaggery, Nutritional value, Consumer acceptability

\section{Article Info}

Accepted:

20 June 2019

Available Online:

10 July 2019

\section{A B S T R A C T}

Jaggery is the natural sweetener and available in solid, liquid \& powder form. The micronutrients which are present in Jaggery has many nutritional \& medicinal aspects like its anti carcinogenic \& antitoxic activity. Jaggery has proved itself better as compared to white sugar. Jaggery is known to produce heat and give instant energy to a human body. Millets are highly nutritious and are known to have good nutritive value and therapeutic use. In developing countries like India with increasing urbanization, the demand for processed food is increasing popularly. Among them, bakery products particularly cookies command wide popularity in both urban and rural mass. Hence, an attempt was made to develop value added jaggery millet cookies with acceptable sensory attributes. The present study was conducted for formulating cookies by substituting sugar with non-organic jaggery and organic jaggery, evaluating physico-chemical analysis; shelf life and consumer acceptability of selected and accepted products were conducted. The findings revealed that, the little millet jaggery based cookies with ratio of 75:25 of sugar: non organic jaggery incorporated little millet cookie and 100:0 of organic-jaggery: sugar incorporated little millet cookie was selected for further evaluations. The physical parameters like bulk density, spread ratio and spread factor did not vary significantly. Iron content was significantly $(\mathrm{p} \leq 5 \%)$ higher in organic jaggery cookies $(2.20 \mathrm{mg} / 100 \mathrm{~g})$. Calcium $(180.10$ $\mathrm{mg} / 100 \mathrm{~g})$ and potassium $(220.0 \mathrm{mg} / 100 \mathrm{~g})$ were higher in non-organic jaggery cookie respectively. Phosphorus did not differ significantly in both $(150 \mathrm{mg} / 100 \mathrm{~g}, 149.6 \mathrm{mg} / 100 \mathrm{~g})$ respectively. Organic jaggery cookie had shelf life of 60 days. Consumer acceptability showed that none of the product was in 'dislike' category for the developed cookies.

\section{Introduction}

An organic food is free of synthetic additives like pesticides, chemical fertilizers and also contains less heavy metal. Jaggery is a natural traditional sweetener, made by concentrating the extracted sugarcane juice. Jaggery been widely used in parts of India, Africa, Latin America, Japan etc. and is technically known as Non Centrifugal Sugar (Walter, 2012). India's climatic conditions are more conducive for sugarcane production thus 
providing the much needed raw material for jaggery production. Almost 3/4th of the cane produced in India is being utilized for producing jaggery. Jaggery is widely used in making sweets and syrups in India and jaggery is a popular part of the cuisines of the Indian subcontinent in preparing various sweet dishes like candy, toffees, jaggery cakes and other similar sweet preparations. Its regular usage is advocated in the daily diet as it is a healthy and unrefined form of sugar.

The awareness among the general public regarding the organic food products has been catching up fast. Consumers are opting more for organic food products due to higher health consciousness. Higher the demand, higher is the supply of new varieties of organic food. Thus giving scope to develop new products with organic value.

Bakery products are one of the areas which require higher diversification in organic food products. There is higher potential to develop bakery products with organic ingredients, which can enhance the qualitative and quantitative factors of the food product, hence the study was undertaken with the objective of development, nutritional characteristics and consumer acceptability of jaggery based cookies.

\section{Materials and Methods}

\section{Procurement of sample}

\section{Ingredients}

Little millet was purchased from the local market and milled in the Department of Food Science. Refined wheat flour, unsalted butter, eggs, non-organic jaggery, organic-jaggery and other additives like sodium bicarbonate, vanilla flavors etc were procured from the local market. Organic jaggery with a brand name "Pro Nature Organic Foods" Pvt. Ltd. a
Bangalore based marketer of organic food product in India was purchased. The product is 100 percent certified organic by an internationally recognized Switzerland based certification body, IMO Control.

\section{Standardization of little millet cookies}

Refined wheat flour cookies recipe developed by Bakery unit, UAS, Dharwad was adopted and varied by replacing refined wheat flour with little millet flour $(0,20,40,60,80$ and $100)$ at various ratios keeping the other ingredients constant.

\section{Method of preparation of cookies}

Flour was sieved with 0.5 per cent baking powder. Fat $(50 \mathrm{~g})$ and powdered sugar $(60 \mathrm{~g})$ was creamed, blended with the flour and made to dough, sheeted for uniform thickness of 0.5 $\mathrm{mm}$, punched manually into circular shapes of $3 \mathrm{~mm}$ diameter, baked at top temperature of $180^{\circ} \mathrm{C}$ and bottom temperature $150{ }^{\circ} \mathrm{C}$ for 20 min, allowed to cool and evaluated.

\section{Optimization for incorporation of jaggery}

The most acceptable proportion of little millet to refined wheat flour cookie was further used to standardize optimum addition of jaggery. Cookies were evaluated for physical and organoleptic characters. Standardization of jaggery based cookies was carried out by replacing sugar with non-organic or organic jaggery by $0,25,50,75,100,125$ and 150 per cent.

\section{Organoleptic evaluation}

The value added cookies were evaluated for organoleptic attributes using 9 point hedonic scale by a panel of 20 semi-trained judges from Department of Food Science and Nutrition, College of Home Science, UAS, Dharwad. 


\section{Nutrient composition of cookies}

Nutrient composition of control and most acceptable -little millet- jaggery cookies were analyzed on moisture free basis in triplicates employing standard procedures (Anon., 1990). Dietary fiber content of all the cookies was analyzed by enzymatic-gravimetric method (Asp et al., 1983).

\section{Consumer acceptability of value added cookies}

Consumer acceptance of most acceptable cookies was carried out among 300 academicians, supporting staff and students of Home Science College; school children, farmers. The consumers were served with one serving of the cookies and opinion was solicited as whether the product was acceptable. The opinion were tabulated and expressed in per cent basis.

\section{Statistical analysis}

Obtained experimental values were analyzed by analysis of variance (ANOVA) and student's $t$ test for comparisons. SPSS software (version 16.0) was used to analyze the data.

\section{Results and Discussion}

\section{Standardization of little millet cookies}

\section{Optimization for incorporation of little millet flour}

For optimization of little millet cookie, the standard recipe with refined wheat flour was adopted (Variation I, Table 1). Keeping the other ingredients constant, variations replacing refined wheat flour with little millet flour at various levels were tried (Table 1). The cookies with these variations were prepared and subjected to descriptive sensory evaluation (Table 2). The maximum acceptable incorporation at 40:60 proportions was selected for further studies and was used as little millet control sample for further studies. Although lower proportions were acceptable, the maximum acceptable incorporation of little millet level was chosen.

Optimization of incorporation of nonorganic-jaggery in little millet cookies

To the selected little millet cookie (40:60), variation III recipe, sugar was replaced with non-organic jaggery as per the proportions given in (Table 3) keeping the other ingredients flour, butter, curds, essence constant.

The cookies were evaluated for organoleptic parameters on a 9 point hedonic scale. The results of the organoleptic evaluations indicate that 75:25 of sugar: non-organic jaggery was on par with the little millet cookie with sugar. As the jaggery ratio increased, the appearance and colour did not vary significantly, while texture, taste, aroma and overall acceptability reduced significantly $(\mathrm{p}<5 \%)$ (Table 4$)$.

\section{Optimization of incorporation of evaluation of organic jaggery with little millet cookies}

Similar to variations made with regard to nonorganic jaggery incorporated little millet cookies (Table 3), variations were made by replacing sugar with organic-jaggery.

The sensory evaluation of organic jaggery incorporated sugar cookies indicates 100 per cent incorporation was acceptable in terms of appearance, colour, texture, taste, aroma and overall acceptability (Table 5). With further increase in organic jaggery levels, the sensory scores decreased for all the parameters. Based on the dough handling comfort the ratio of 25:75 sugar: organic jaggery level was chosen for further evaluations. 
Physical parameters of little millet cookies with sugar, non-organic and organic jaggery

The physical parameters of cookies like weight, diameter and volume both the types of jaggery incorporated cookies had significantly lower values compared to little millet cookies with sugar, However bulk density, spread ratio and spread factor did not vary significantly (Table 6). The change in weight could be because of functional properties of sugar. The slight increase in weight may be due to difference in moisture retention level.

The colour scores in all the three cookies, significantly different in all parameters $\left(\mathrm{L}^{*}\right)$ lightness (64.94), $\left(\mathrm{a}^{*}\right)$ red to green (13.70) and $\left(b^{*}\right)$ yellow to green (34.07) was significantly different $(\mathrm{p}<5 \%)$ higher in sugar cookies, while lightness was similarly in both jaggery cookies. Compared to both jaggery, red to green and yellow to green values were higher in organic jaggery cookies (10.63 and 31.68) followed by non-organic jaggery cookies (8.82 and 27.67) (Table 7).

Nutritional profile of little millet cookies with sugar, non-organic and organic jaggery

Table 8 depicts the nutritional composition of different types of cookies. Fat, ash, crude fiber, carbohydrates did not vary significantly among all the types of cookies. Protein was significantly higher $(\mathrm{p}<5 \%)$ in little millet cookies with sugar $(12.94 \mathrm{~g} / 100 \mathrm{~g})$ compared to organic jaggery $(12.12 \mathrm{~g} / 100 \mathrm{~g})$ and nonorganic jaggery $(12.04 \mathrm{~g} / 100 \mathrm{~g})$ incorporated little cookies. Dietary fiber was least in organic jaggery incorporated little millet cookie $(1.5 \pm 0.34)$ and was significantly lower $(\mathrm{p}<5 \%)$ than little millet cookie with sugar $(2.40 \mathrm{~g} / 100 \mathrm{~g})$. While dietary fiber in non-organic jaggery incorporated cookies $(2.05 \mathrm{~g} / 100 \mathrm{~g})$ did not differ significantly with both the types of cookies $(2.40 \mathrm{~g} / 100 \mathrm{~g}, 1.50$ $\mathrm{g} / 100 \mathrm{~g}$ ). Carbohydrates was found to be high in case of organic jaggery incorporated little millet cookies.

\section{Mineral content of little millet cookies with sugar, non-organic and organic jaggery}

Calcium, iron, potassium, phosphorus content in the little millet cookies with sugar, nonorganic jaggery and organic jaggery are depicted in table 9. All the minerals estimated i.e. Calcium, iron, phosphorus and potassium were significantly lower in little millet cookies added with sugar. Incorporation of jaggery either organic or non-organic significantly increased all the mineral content estimated. When both the jaggery cookies are compared iron content was significantly ( $\mathrm{p}<5 \%$ ) higher in organic jaggery cookies $(2.20 \mathrm{mg} / 100 \mathrm{~g})$. Calcium and potassium was higher in nonorganic jaggery cookie $(180.10 \mathrm{mg} / 100 \mathrm{~g})$ and (220.0mg/100g) respectively. Phosphorus did not differ significantly in both the types of jaggery cookies $(150 \mathrm{mg} / 100 \mathrm{~g}, 149.6 \mathrm{mg} / 100 \mathrm{~g})$ respectively.

Consumer acceptability of jaggery cookies with sugar, non-organic and organic jaggery

The accepted levels of organic jaggery and non- organic jaggery substituted little millet sugar cookies were tested for consumer acceptance (Table10). A sample of 300 members consisting of school children, college students, faculty, labours, farmers evaluated the products on a five point rating. The results indicated that in case of nonorganic jaggery cookies, $186(62 \%)$ liked extremely, $111(37 \%)$ liked slightly and 30 $(10 \%)$ neither liked nor disliked of the diverse group of consumers. In case of organic jaggery out of 300, 171(57\%) liked extremely, 99(33\%) like slightly and $30(10 \%)$ neither liked nor disliked. However, none of the 
respondents were in 'dislike' category for developed cookies.

\section{Standardization of little millet cookies and optimization of incorporation of non- organic and organic jaggery}

Normally cookies are made of refined wheat flour, hydrogenated fat/ butter, refined sugar, as major ingredients and baking powder, flavor substances milk or curds as minor ingredients. In the present investigation, regular cookie recipe was modified by replacing refined wheat flour with various levels of little millet flour, keeping all the other ingredients constant. Descriptive analysis of the products was carried out by trained judges. Incorporation of little millet flour in cookies was acceptable upto 60 per cent, beyond that the cookies were hard in texture and the mouth feel was gritty which could be due to particle size of little millet flour. The physical parameters like spread ability was less. Hemalatha et al., (2006) reported that cookies incorporated with little millet exhibited lower spread ratio and spread factor. The barnyard millet cookies developed by Balloli (2010) resulted in gritty mouth feel, hard texture and had less spreading capacity of cookies and was attributed to a major portion $(50.10 \%)$ of barnyard millet flour consisting of coarser particles of $250 \mu$ size. Similar increased hardness was reported in sorghum cookies by Munck (1995), wherein the vitreous endosperm adversely affected the texture of the cookies. It was attributed to the kafirin complex (the prolamin storage protein of sorghum) which encapsulates the starch granules, making it highly hydrophobic, retarding water uptake and gelatinization. Increased hardness was also reported in pearl millet cookies by Mridula and Gupta (2008), which increased as the level of pearl millet incorporation increased and they attributed the phenomenon to the higher fiber content of pearl millet. In the present investigation the level of 40:60 refined flour: little millet flour ratio was considered based on the sensory evaluations for further studies.

For optimization of incorporation of jaggery in the cookies at 40:60, of refined flour: little millet flour with sugar was modified by substituting sugar with various levels of jaggery, either organic or non-organic. With regard to non-organic jaggery cookies, 75:25 ratio of sugar: non-organic jaggery scored higher. The increase in the jaggery percentage resulted in harder and bitter cookies without affecting the other sensory parameters like appearance and colour. The bitterness of the higher jaggery incorporated cookies could be due to the constituents used in production of jaggery and hardness may be due to textural attributes of jaggery. Sugar and jaggery differ a great deal in texture. While sugar crystals are solid and hard, jaggery is semi-solid, softer than sugar and also amorphous Shrivastav et al., (2016) case of organic jaggery, although 100 per cent substitution was acceptable by sensory evaluation, 25: 75 sugar: organic jaggery was opted for further studies, due to uncomfortability in dough handling with use of higher proportion of jaggery the next accepted level was chosen for further evaluations. The researcher observed textural variation between the two types of i.e., jaggery, and organic jaggery was smoother and less crystalline compared to non-organic jaggery.

Physicochemical profile of little millet cookies with sugar and non-organic and organic jaggery

The selected cookies-sugar (100\%), organic $(75 \%)$ and non-organic jaggery (25\%) incorporated were subjected to physical analysis like weight, volume, bulk density diameter, spread ratio and spread factor. When compared to the little millet cookies with sugar, the only change noticed in jaggery 
cookies was with regard to weight and all the other parameters did not differ significantly. The change in weight could be because of functional properties of sugar. The slight increase in weight may be due to difference in moisture retention level.

The texture profile analysis curves (Fig. 1) indicates that in control cookies, fracturability occurred at approximately $1,190 \mathrm{~g}$ force and 2 seconds and incase of non-organic jaggery cookie, the fracturability occurred at approximately $920 \mathrm{~g}$ force and 1 second and in case of organic jaggery cookie, the product fractured many times as it was compressed. The first instance occurred at approximately $470 \mathrm{~g}$ and 0.7 seconds. Thus indicating organic cookie was easily breakable followed by non-organic and little millet sugar cookie. These textural variations may be attributed to the textural differences in sugar and jaggery. Contrary to the results of Balloli (2010), wherein the barnyard millet cookies were thick, compact, less spread with harder texture requiring higher force/strength of $5066.09 \mathrm{~g}$ to break the cookies compared to control cookies which required only $3859.20 \mathrm{~g}$ force to break. In the present study little millet cookies with jaggery and specially organic jaggery was comparatively softer. Jaggery contains varying amounts of glucose+fructose compared to sucrose depending on the extent of hydrolysis during heat treatment to remove water during jaggery production. Monosaccharides tend to make the product softer and chewy (Pai, 2006).

The nutritional composition of little millet cookies with sugar, non- organic jaggery and organic jaggery indicated significant $(\mathrm{p}<5 \%)$ variation with regard to protein and carbohydrate content. Protein was slightly higher in sugar based and carbohydrate was higher in organic jaggery based cookies. With regard to mineral composition variations were significant. Both the types of jaggery incorporation increased the mineral content - calcium, iron, phosphorus and potassium, although the incorporation of non-organic jaggery was lesser compared to organic jaggery. The difference in calcium and potassium content between organic and nonorganic jaggery cookies might be due to the additives used in jaggery production, where in calcium oxide is used in non- organic jaggery production. Increase in iron may be from the pans used in the preparation. Studies by Venkatasubramanian (2011) on the nutritional quality and acceptability of organic and conventional foods have also reported similar results with higher protein and mineral content in organic jaggery than conventional jaggery sweet based pongal.

\section{Consumer acceptability of little millet cookies and muffins with jaggery}

Consumer attitudes towards any food products depend upon several factors. Culture, food habits, life style, geographical location, season etc influence the food preference. Consumer's acceptability is the main component to marketability of the products. Today consumers are aware of health concepts and demand foods that not only taste good but also provide nutrition and health benefits. Consumer acceptability test of jaggery cookies was carried out with different age groups of consumers. The results indicate the maximum number of consumers preferred non- organic jaggery cookies compared to organic cookies. Among the different categories of people, school going children and farmers liked extremely due to texture and colour. While faculty, students and labours of UAS, Dharwad, have liked extremely the organic jaggery cookies. The reasons for liking were because of aroma and they believed it to be healthy. Very few people expressed neither like nor dislikes and none of them disliked the products. Thus it could be inferred that the products are liked by all age groups and could be a potential marketable product. 
Table.1 Standardization of cookies with little millet flour

\begin{tabular}{|c|c|c|c|c|c|c|c|}
\hline Variations & $\begin{array}{c}\text { Refined } \\
\text { wheat } \\
\text { flour } \\
\text { (g) }\end{array}$ & $\begin{array}{c}\text { Little } \\
\text { millet } \\
\text { flour } \\
\text { (g) }\end{array}$ & $\begin{array}{c}\text { Butter } \\
\text { (g) }\end{array}$ & $\begin{array}{l}\text { Sugar } \\
(\mathrm{g})\end{array}$ & $\begin{array}{c}\text { Curd } \\
\text { Tsp }\end{array}$ & $\begin{array}{c}\text { Baking } \\
\text { powder } \\
\text { (g) }\end{array}$ & $\begin{array}{c}\text { Essence } \\
\text { (vanilla) } \\
\text { drops }\end{array}$ \\
\hline I & 100 & 0 & \multirow{4}{*}{50} & \multirow{4}{*}{60} & \multirow{4}{*}{2} & \multirow{4}{*}{0.5} & \multirow{4}{*}{$2-3$} \\
\hline II & 60 & 40 & & & & & \\
\hline III & 40 & 60 & & & & & \\
\hline IV & 20 & 80 & & & & & \\
\hline
\end{tabular}

Table.2 Descriptive profile of little millet flour incorporated cookies

\begin{tabular}{|c|c|l|}
\hline Variations & $\begin{array}{c}\text { Refined flour: little } \\
\text { millet flour }(\mathbf{g})\end{array}$ & \multicolumn{1}{|c|}{ Descriptive profile of cookies } \\
\hline Control & $100: 00$ & $\begin{array}{l}\text { Golden brown, evenly baked, attractive, well spread, light and } \\
\text { crisp, pleasant baked aroma and flavor, smooth in mouth feel } \\
\text { and acceptable. }\end{array}$ \\
\hline I & $80: 20$ & $\begin{array}{l}\text { Creamish, evenly baked, attractive, well spread, slightly } \\
\text { compact, pleasant baked aroma and flavor, slight coarse mouth } \\
\text { feel and acceptable. }\end{array}$ \\
\hline II & $60: 40$ & $\begin{array}{l}\text { Dull creamish, evenly baked, slight compact, crisp, pleasant } \\
\text { baked aroma and flavor slightly coarse mouth feel and } \\
\text { acceptable. }\end{array}$ \\
\hline III & $40: 60$ & $\begin{array}{l}\text { Dull creamish, evenly baked, slight compact, crisp, pleasant } \\
\text { baked aroma and flavor slightly coarse mouth feel and } \\
\text { acceptable. }\end{array}$ \\
\hline IV & $20: 80$ & $\begin{array}{l}\text { Off white, evenly baked, less spread, highly compact, brittle } \\
\text { and gritty mouths feel, unacceptable. }\end{array}$ \\
\hline
\end{tabular}

Table.3 Incorporation of non-organic and organic jaggery in little millet cookies

\begin{tabular}{|c|c|c|c|c|}
\hline Variations & Sugar (g) & $\begin{array}{c}\text { Non-organic } \\
\text { jaggery }(\mathbf{g})\end{array}$ & $\begin{array}{c}\text { Organic jaggery } \\
(\mathbf{g})\end{array}$ & $\begin{array}{c}\text { Ratio } \\
\text { (sugar : jaggery) } \\
\text { Per cent }\end{array}$ \\
\hline $\mathbf{1}$ & & & & $100: 00$ \\
\hline $\mathbf{2}$ & 60 & 0 & 0 & $75: 25$ \\
\hline $\mathbf{3}$ & 45 & 15 & 15 & $50: 50$ \\
\hline $\mathbf{4}$ & 30 & 30 & 30 & $25: 75$ \\
\hline $\mathbf{5}$ & 15 & 45 & 45 & $00: 100$ \\
\hline $\mathbf{6}$ & - & 60 & 60 & $00: 125$ \\
\hline $\mathbf{7}$ & - & 70 & 70 & $00: 150$ \\
\hline
\end{tabular}


Table.4 Sensory profile of little millet cookies with non-organic jiggery

\begin{tabular}{|c|c|c|c|c|c|c|c|c|c|c|}
\hline Variations & 1 & 2 & 3 & 4 & 5 & 6 & 7 & \multirow[t]{2}{*}{$\mathbf{F}$} & \multirow{2}{*}{$\begin{array}{c}\text { S. } \\
\text { Em. } \\
\pm\end{array}$} & \multirow[t]{2}{*}{ CD } \\
\hline $\begin{array}{l}\text { Sugar : } \\
\text { Jaggery }\end{array}$ & 100:00:00 & $75: 25: 00$ & $50: 50: 00$ & $25: 75$ & 0.06944 & 0.08681 & 0.10417 & & & \\
\hline Appearance & $\begin{array}{l}8.22 \pm \\
0.75^{a}\end{array}$ & $\begin{array}{l}7.96 \pm \\
0.75^{\mathrm{a}}\end{array}$ & $\begin{array}{l}7.88 \pm \\
1.01^{\mathrm{a}}\end{array}$ & $\begin{array}{l}8.14 \pm \\
0.71^{\mathrm{a}}\end{array}$ & $\begin{array}{l}8.14 \pm \\
0.71^{\mathrm{a}}\end{array}$ & $\begin{array}{l}8.00 \pm \\
0.78^{a}\end{array}$ & $\begin{array}{c}7.85 \pm \\
0.76^{\mathrm{a}}\end{array}$ & 0.92 & 0.15 & NS \\
\hline Color & $\begin{array}{l}8.29 \pm \\
0.82^{a}\end{array}$ & $\begin{array}{c}8.11 \pm \\
0.69^{\mathrm{a}}\end{array}$ & $\begin{array}{c}8.07 \pm \\
0.91^{\mathrm{a}}\end{array}$ & $\begin{array}{l}7.85 \pm \\
0.76^{\mathrm{a}}\end{array}$ & $\begin{array}{c}7.85 \pm \\
0.81^{\mathrm{a}}\end{array}$ & $\begin{array}{l}8.03 \pm \\
0.75^{\mathrm{a}}\end{array}$ & $\begin{array}{l}7.81 \pm \\
0.78^{\mathrm{a}}\end{array}$ & 0.8 & 0.15 & NS \\
\hline Texture & $\begin{array}{l}8.40 \pm \\
0.74^{\mathrm{a}}\end{array}$ & $\begin{array}{l}8.11 \pm \\
0.75^{\mathrm{ab}}\end{array}$ & $\begin{array}{l}7.62 \pm \\
0.96^{\mathrm{abc}}\end{array}$ & $\begin{array}{l}7.74 \pm \\
0.85^{\mathrm{bc}}\end{array}$ & $\begin{array}{l}7.51 \pm \\
0.64^{\mathrm{cd}}\end{array}$ & $\begin{array}{l}7.18 \pm \\
1.03^{\mathrm{de}}\end{array}$ & $\begin{array}{c}6.98 \pm \\
1.24^{\mathrm{e}}\end{array}$ & 7.76 & 0.17 & $0.44 * *$ \\
\hline Taste & $\begin{array}{c}8.03 \pm \\
0.80^{\mathrm{a}}\end{array}$ & $\begin{array}{l}7.88 \pm \\
0.84^{\mathrm{ab}}\end{array}$ & $\begin{array}{l}7.86 \pm \\
0.98^{\mathrm{ab}}\end{array}$ & $\begin{array}{l}7.79 \pm \\
0.77^{\mathrm{ab}}\end{array}$ & $\begin{array}{c}7.90 \pm \\
0.19^{\mathrm{a}}\end{array}$ & $\begin{array}{l}7.37 \pm \\
0.83^{\mathrm{c}}\end{array}$ & $\begin{array}{l}7.48 \pm \\
0.80^{\mathrm{bc}}\end{array}$ & 3.2 & 0.14 & $0.41 *$ \\
\hline Aroma & $\begin{array}{c}8.03 \pm \\
0.70^{\mathrm{a}}\end{array}$ & $\begin{array}{l}7.85 \pm \\
0.71^{\mathrm{ab}}\end{array}$ & $\begin{array}{l}7.70 \pm \\
0.81^{\mathrm{ab}}\end{array}$ & $\begin{array}{l}7.55 \pm \\
0.84^{\mathrm{ab}}\end{array}$ & $\begin{array}{c}7.51 \pm \\
0.89^{\mathrm{b}}\end{array}$ & $\begin{array}{l}7.51 \pm \\
0.89^{\mathrm{b}}\end{array}$ & $\begin{array}{l}7.60 \pm \\
0.88^{\mathrm{ab}}\end{array}$ & 1.08 & 0.16 & NS \\
\hline $\begin{array}{c}\text { Overall } \\
\text { acceptability }\end{array}$ & $\begin{array}{l}8.10 \pm \\
0.76^{\mathrm{a}}\end{array}$ & $\begin{array}{l}8.00 \pm \\
0.670^{\mathrm{ab}}\end{array}$ & $\begin{array}{l}7.81 \pm \\
0.83^{\mathrm{abc}}\end{array}$ & $\begin{array}{l}7.77 \pm \\
0.80^{\mathrm{abc}}\end{array}$ & $\begin{array}{l}7.62 \pm \\
0.74^{\mathrm{bc}}\end{array}$ & $\begin{array}{c}7.44 \pm \\
0.89^{c}\end{array}$ & $\begin{array}{c}7.37 \pm \\
0.88^{\mathrm{c}}\end{array}$ & 3.31 & 0.15 & $0.43 * *$ \\
\hline $\begin{array}{l}\text { Acceptability } \\
\text { index }\end{array}$ & 90.87 & 88.72 & 86.92 & 86.74 & 86.66 & 84.25 & 83.5 & & & \\
\hline
\end{tabular}

Values are expressed as mean \pm SD of triplicate

$* *$ the values are significantly different at $\mathrm{p} \leq 0.01$,

*the values are significantly different at $p \leq 0.05$, NS-Non-significant,

The same superscript letters within a row are not significantly different.

Table.5 Sensory profile of little millet cookies with organic jiggery

\begin{tabular}{|c|c|c|c|c|c|c|c|c|c|c|}
\hline Variations & 1 & 2 & 3 & 4 & 5 & 6 & 7 & $\mathbf{F}$ & S. & CD \\
\hline $\begin{array}{l}\text { Sugar : } \\
\text { Jaggery }\end{array}$ & 100:0 & $75: 25: 00$ & $50: 50: 00$ & $25: 75$ & 0.06944 & 0.08681 & 0.10417 & & $\begin{array}{c}\text { Em. } \\
\pm\end{array}$ & \\
\hline Appearance & $\begin{array}{c}8.80 \\
\pm \\
0.40^{\mathrm{a}}\end{array}$ & $\begin{array}{l}7.71 \pm \\
0.90^{\mathrm{bc}}\end{array}$ & $\begin{array}{l}7.66 \pm \\
0.91^{\mathrm{cb}}\end{array}$ & $\begin{array}{l}8.14 \pm \\
0.69^{\mathrm{cb}}\end{array}$ & $\begin{array}{l}7.80 \pm \\
0.79^{\mathrm{b}}\end{array}$ & $\begin{array}{l}7.42 \pm \\
0.92^{\mathrm{cb}}\end{array}$ & $\begin{array}{l}7.23 \pm \\
1.09^{c}\end{array}$ & 7 & 0.18 & $0.55^{* *}$ \\
\hline Color & $\begin{array}{c}8.71 \\
\pm \\
0.56^{\mathrm{a}}\end{array}$ & $\begin{array}{l}7.66 \pm \\
0.85^{\mathrm{bc}}\end{array}$ & $\begin{array}{l}7.76 \pm \\
0.94^{\mathrm{bc}}\end{array}$ & $\begin{array}{l}8.07 \pm \\
0.88^{\mathrm{cb}}\end{array}$ & $\begin{array}{l}8.00 \pm \\
0.77^{\mathrm{b}}\end{array}$ & $\begin{array}{c}7.33 \pm \\
0.91^{\mathrm{c}}\end{array}$ & $\begin{array}{l}7.50 \pm \\
1.03^{\mathrm{bc}}\end{array}$ & 5.5 & 0.19 & $0.52 * *$ \\
\hline Texture & $\begin{array}{c}8.66 \\
\pm \\
0.57^{\mathrm{a}}\end{array}$ & $\begin{array}{l}7.66 \pm \\
0.85^{b}\end{array}$ & $\begin{array}{l}7.61 \pm \\
0.80^{b}\end{array}$ & $\begin{array}{l}7.62 \pm \\
0.56^{b}\end{array}$ & $\begin{array}{l}8.00 \pm \\
0.70^{b}\end{array}$ & $\begin{array}{c}6.76 \pm \\
1.13^{\mathrm{c}}\end{array}$ & $\begin{array}{l}6.23 \pm \\
1.41^{c}\end{array}$ & 15.42 & 0.2 & $0.45^{* *}$ \\
\hline Taste & $\begin{array}{c}8.28 \\
\pm \\
0.84^{\mathrm{a}}\end{array}$ & $\begin{array}{l}7.90 \pm \\
0.83^{a}\end{array}$ & $\begin{array}{l}7.85 \pm \\
0.96^{\mathrm{a}}\end{array}$ & $\begin{array}{l}8.00 \pm \\
0.00^{\mathrm{ab}}\end{array}$ & $\begin{array}{l}8.00 \pm \\
0.77^{a}\end{array}$ & $\begin{array}{l}7.00 \pm \\
1.14^{\mathrm{b}}\end{array}$ & $\begin{array}{c}6.28 \pm \\
1.82^{c}\end{array}$ & 7.46 & 0.25 & $0.52 * *$ \\
\hline Aroma & $\begin{array}{c}8.23 \\
\pm \\
0.94^{\mathrm{a}}\end{array}$ & $\begin{array}{l}7.85 \pm \\
0.85^{\mathrm{a}}\end{array}$ & $\begin{array}{l}7.66 \pm \\
0.85^{\mathrm{bc}}\end{array}$ & $\begin{array}{l}7.59 \pm \\
0.90^{\mathrm{a}}\end{array}$ & $\begin{array}{l}7.70 \pm \\
0.76^{a}\end{array}$ & $\begin{array}{l}7.14 \pm \\
0.91^{\mathrm{bc}}\end{array}$ & $\begin{array}{l}7.00 \pm \\
1.34^{\mathrm{c}}\end{array}$ & 4.41 & 0.2 & $0.55^{* *}$ \\
\hline $\begin{array}{c}\text { Overall } \\
\text { acceptability }\end{array}$ & $\begin{array}{c}8.61 \\
\pm \\
0.58^{a}\end{array}$ & $\begin{array}{l}7.66 \pm \\
0.79^{\mathrm{b}}\end{array}$ & $\begin{array}{l}7.90 \pm \\
0.70^{\mathrm{b}}\end{array}$ & $\begin{array}{l}7.70 \pm \\
0.76^{b}\end{array}$ & $\begin{array}{l}7.85 \pm \\
0.47^{\mathrm{b}}\end{array}$ & $\begin{array}{l}7.00 \pm \\
1.22^{c}\end{array}$ & $\begin{array}{l}6.52 \pm \\
1.40^{c}\end{array}$ & 11.39 & 0.19 & $0.44 * *$ \\
\hline $\begin{array}{c}\text { Acceptability } \\
\text { index }\end{array}$ & 94.98 & 86 & 86 & 87.25 & 87.68 & 78 & 75.48 & & & \\
\hline
\end{tabular}


Table.6 Physical parameters of little millet cookies with sugar, non-organic and organic jiggery

\begin{tabular}{|c|c|c|c|c|c|c|c|}
\hline $\begin{array}{l}\text { Little millet } \\
\text { cookie }\end{array}$ & Weight (g) & $\begin{array}{l}\text { Diameter } \\
(\mathbf{m m})\end{array}$ & $\begin{array}{c}\text { Thickness } \\
\text { (mm) }\end{array}$ & Volume (ml) & $\begin{array}{c}\text { Bulky density } \\
(\mathrm{g} / \mathrm{ml})\end{array}$ & $\begin{array}{l}\text { Spread } \\
\text { ratio }\end{array}$ & Spread factor \\
\hline Sugar & $4.31 \pm 0.00^{\mathrm{a}}$ & $3.90 \pm 0.00^{\mathrm{a}}$ & $3.42 \pm 0.01^{\mathrm{a}}$ & $13.00 \pm 0.00^{\mathrm{a}}$ & $0.33 \pm 0.00^{b}$ & $1.25 \pm 0.00^{\mathrm{a}}$ & $100.00 \pm 0.00^{\mathrm{a}}$ \\
\hline $\begin{array}{c}\text { Non-organic } \\
\text { jaggery }\end{array}$ & $4.13 \pm 0.01^{b}$ & $3.65 \pm 0.00^{\mathrm{a}}$ & $3.10 \pm 0.00^{\mathrm{a}}$ & $10.00 \pm 0.00^{\mathrm{a}}$ & $0.41 \pm 0.00^{\mathrm{a}}$ & $1.32 \pm 0.00^{\mathrm{a}}$ & $98.6 \pm 0.00^{\mathrm{a}}$ \\
\hline $\begin{array}{l}\text { Organic } \\
\text { jaggery }\end{array}$ & $4.08 \pm 0.08^{b}$ & $3.63 \pm 0.02^{\mathrm{a}}$ & $3.21 \pm 0.01^{\mathrm{a}}$ & $10.00 \pm 0.00^{\mathrm{a}}$ & $00.40 \pm 0.00^{\mathrm{a}}$ & $1.35 \pm 0.12^{\mathrm{a}}$ & $99.5 \pm 0.45^{\mathrm{a}}$ \\
\hline $\mathbf{F}$ & 19.54 & 24.1 & 39.65 & 29.4 & 55.30 & 14.53 & 26.68 \\
\hline S. Em. \pm & 0.03 & 0.01 & 0.09 & 0.01 & 0.01 & 0.04 & 0.15 \\
\hline CD & $0.094 * *$ & NS & NS & NS & NS & NS & NS \\
\hline
\end{tabular}

Table.7 Color parameters of little millet cookies with sugar, non-organic and organic jiggery

\begin{tabular}{|c|c|c|c|}
\hline Little millet cookies & $\mathbf{L}^{*}$ & $\mathbf{a}^{*}$ & $\mathbf{b}^{*}$ \\
\hline Sugar & $64.94 \pm 7.69^{\mathrm{a}}$ & $13.70 \pm 0.98^{\mathrm{a}}$ & $34.07 \pm 2.78^{\mathrm{a}}$ \\
\hline Non-organic jaggery & $63.58 \pm 2.09^{\mathrm{b}}$ & $8.82 \pm 2.27^{\mathrm{c}}$ & $27.67 \pm 0.24^{\mathrm{c}}$ \\
\hline Organic jaggery & $63.49 \pm 2.59^{\mathrm{b}}$ & $10.63 \pm 0.68^{\mathrm{b}}$ & $31.68 \pm 0.50^{\mathrm{b}}$ \\
\hline F & 853.64 & 113.92 & 429.75 \\
\hline S.Em. \pm & 2.67 & 1.20 & 0.91 \\
\hline CD & $9.25^{* *}$ & $4.18^{* *}$ & $3.15^{* *}$ \\
\hline
\end{tabular}

Values are expressed as mean $\pm \mathrm{SD}$ of triplicate

$* *$ the values are significantly different at $\mathrm{p} \leq 0.01$,

*the values are significantly different at $p \leq 0.05$, NS-Non-significant.

The same superscript letters within a column are not significantly different.

Table.8 Nutrient content of little millet cookies with sugar, non-organic and organic jaggery per100 gram

\begin{tabular}{|c|c|c|c|c|c|c|}
\hline $\begin{array}{l}\text { Little millet } \\
\text { cookies }\end{array}$ & Sugar & $\begin{array}{c}\text { Non-organic } \\
\text { jaggery }\end{array}$ & $\begin{array}{l}\text { Organic } \\
\text { jaggery }\end{array}$ & $\mathbf{F}$ & $\begin{array}{c}\text { S. Em. } \\
\pm\end{array}$ & CD \\
\hline \begin{tabular}{l|l} 
Energy & (Kcal)
\end{tabular} & $449.00 \pm 3.00^{\mathrm{a}}$ & $452.40 \pm 1.33^{\mathrm{a}}$ & $448.90 \pm 3.92^{\mathrm{a}}$ & 1.38 & 1.72 & NS \\
\hline Moisture (\%) & $5.36 \pm 0.40^{\mathrm{a}}$ & $5.20 \pm 0.40^{\mathrm{a}}$ & $5.30 \pm 0.45^{\mathrm{a}}$ & 0.05 & 0.24 & NS \\
\hline Protein (g) & $12.94 \pm 0.21^{\mathrm{a}}$ & $12.04 \pm 0.15^{b}$ & $12.12 \pm 0.33^{b}$ & 12.44 & 0.14 & $0.4 * *$ \\
\hline Fat (g) & $14.70 \pm 0.51^{\mathrm{a}}$ & $15.30 \pm 0.10^{\mathrm{a}}$ & $14.63 \pm 041^{\mathrm{a}}$ & 2.56 & 0.22 & NS \\
\hline $\operatorname{Ash}(\mathrm{g})$ & $0.74 \pm 0.17^{\mathrm{a}}$ & $0.77 \pm 0.31^{\mathrm{a}}$ & $0.77 \pm 0.12^{a}$ & 0.01 & 0.12 & NS \\
\hline Crude fiber (g) & $0.53 \pm 0.35^{a}$ & $0.71 \pm 0.24^{\mathrm{a}}$ & $0.67 \pm 0.24^{\mathrm{a}}$ & 0.32 & 0.16 & NS \\
\hline Carbohydrate (g) & $66.24 \pm 0.68^{b}$ & $66.68 \pm 0.28^{b}$ & $67.17 \pm 0.67^{\mathrm{a}}$ & 6.44 & 0.18 & $0.62 *$ \\
\hline Dietary fiber (g) & $2.40 \pm 0.40^{\mathrm{a}}$ & $2.05 \pm 0.11^{\mathrm{ab}}$ & $1.50 \pm 0.34^{b}$ & 1.91 & 0.33 & NS \\
\hline
\end{tabular}

Values are expressed as mean \pm SD of triplicate

$* *$ the values are significantly different at $\mathrm{p} \leq 0.01$,

*the values are significantly different at $p \leq 0.05$, NS-Non-significant,

The same superscript letters within a column are not significantly different. 
Table.9 Mineral content of little millet cookies with sugar, non-organic and organic jaggery per 100 gram

\begin{tabular}{|c|c|c|c|c|}
\hline $\begin{array}{c}\text { Little millet } \\
\text { cookies }\end{array}$ & Calcium $(\mathbf{m g})$ & Iron $(\mathbf{m g})$ & Potassium $(\mathbf{m g})$ & Phosphorus (mg) \\
\hline Sugar & $10.20 \pm 0.64^{\mathrm{c}}$ & $0.59 \pm 0.10^{\mathrm{c}}$ & $120.30 \pm 0.68^{\mathrm{c}}$ & $16.30 \pm 0.41^{\mathrm{b}}$ \\
\hline Non-organic & $180.10 \pm 1.10^{\mathrm{a}}$ & $1.90 \pm 0.05^{\mathrm{b}}$ & $220.00 \pm 3.00^{\mathrm{a}}$ & $149.60 \pm 0.80^{\mathrm{a}}$ \\
\hline Organic & $160.20 \pm 0.64^{\mathrm{b}}$ & $2.20 \pm 0.05^{\mathrm{a}}$ & $190.00 \pm 0.64^{\mathrm{b}}$ & $150.00 \pm 0.55^{\mathrm{a}}$ \\
\hline F & 207.33 & 114.26 & 128.08 & 550.92 \\
\hline S.Em. \pm & 0.49 & 0.045 & 1.04 & 0.35 \\
\hline CD & $2.3^{*}$ & $0.2^{*}$ & $2.5^{*}$ & $0.98^{* *}$ \\
\hline
\end{tabular}

Values are expressed as mean \pm SD of triplicate

$* *$ the values are significantly different at $p \leq 0.01$,

*the values are significantly different at $\mathrm{p} \leq 0.05$, NS-Non-significant,

The same superscript letters within a column are not significantly different.

Table.10 Consumer acceptance of non-organic and organic jaggery cookies 300

\begin{tabular}{|c|c|c|c|c|c|c|c|c|c|c|c|c|}
\hline \multirow{2}{*}{$\begin{array}{l}\text { Consumer } \\
\text { groups }\end{array}$} & \multicolumn{6}{|c|}{ Non-organic jaggery cookies } & \multicolumn{6}{|c|}{ Organic jaggery cookies } \\
\hline & (n) & 1 & 2 & 3 & 4 & 5 & (n) & 1 & 2 & 3 & 4 & 5 \\
\hline School children & $\begin{array}{c}40 \\
(13.30)\end{array}$ & $\begin{array}{c}34 \\
(85.00)\end{array}$ & $\begin{array}{c}3 \\
(7.50)\end{array}$ & $\begin{array}{c}3 \\
(7.50)\end{array}$ & - & - & $\begin{array}{c}40 \\
(13.30)\end{array}$ & $\begin{array}{c}20 \\
(50.00)\end{array}$ & $\begin{array}{c}16 \\
(40.00)\end{array}$ & $\begin{array}{c}4 \\
(10.00)\end{array}$ & - & - \\
\hline $\begin{array}{r}\text { UAS co } \\
\text { stude }\end{array}$ & $\begin{array}{c}80 \\
(26.60)\end{array}$ & $\begin{array}{c}40 \\
(50.00)\end{array}$ & $\begin{array}{c}40 \\
(50.00)\end{array}$ & -- & - & - & $\begin{array}{c}80 \\
(26.60)\end{array}$ & $\begin{array}{c}46 \\
(57.50)\end{array}$ & $\begin{array}{c}20 \\
(25.00)\end{array}$ & $\begin{array}{c}14 \\
(17.50)\end{array}$ & - & -- \\
\hline $\begin{array}{l}\text { Faculty ofUAS, } \\
\text { DharwadCampus }\end{array}$ & $\begin{array}{c}80 \\
(26.60)\end{array}$ & $\begin{array}{c}53 \\
(66.20)\end{array}$ & $\begin{array}{c}27 \\
(33.70)\end{array}$ & -- & - & - & $\begin{array}{c}80 \\
(26.60)\end{array}$ & $\begin{array}{c}55 \\
(68.70)\end{array}$ & $\begin{array}{c}13 \\
(32.50)\end{array}$ & $\begin{array}{c}12 \\
(15.00)\end{array}$ & - & - \\
\hline Labour (hostel) & $\begin{array}{c}50 \\
(16.60)\end{array}$ & $\begin{array}{c}25 \\
(50.00)\end{array}$ & $\begin{array}{c}25 \\
(50.00)\end{array}$ & -- & - & - & $\begin{array}{c}50 \\
(16.60)\end{array}$ & $\begin{array}{c}30 \\
(60.00)\end{array}$ & $\begin{array}{c}20 \\
(40.00)\end{array}$ & --- & - & - \\
\hline Farmer & $\begin{array}{c}50 \\
(16.60)\end{array}$ & $\begin{array}{c}34 \\
(68.00)\end{array}$ & $\begin{array}{c}16 \\
(32.00)\end{array}$ & -- & - & - & $\begin{array}{c}50 \\
(16.60)\end{array}$ & $\begin{array}{c}20 \\
(40.00)\end{array}$ & $\begin{array}{c}30 \\
(60.00)\end{array}$ & --- & - & - \\
\hline Total & 300 & $\begin{array}{c}186 \\
(62.00)\end{array}$ & $\begin{array}{c}111 \\
(37.00)\end{array}$ & $\begin{array}{c}3 \\
(1.00)\end{array}$ & & & 300 & $\begin{array}{c}171 \\
(57.00)\end{array}$ & $\begin{array}{c}99 \\
(33.00)\end{array}$ & $\begin{array}{c}30 \\
(10.00)\end{array}$ & & \\
\hline
\end{tabular}

1- Like extremely, 2- Like slightly, 3- Neither like nor dislike, 4- Dislike slightly, 5-Dislike extremely. Figures in parenthesis indicate percentage.

Thus this study infers that highly acceptable cookies could be prepared with higher incorporation of organic jaggery compared to non-organic jaggery. The cookies offer higher minerals and could be stored for 60 days.

From the study it can be concluded that organic jaggery could replace sugar by 75 per cent and non-organic jaggery by 25 per cent acceptable which was high in protein, carbohydrate and minerals and physical parameters were on par with control. Products developed from little millet are nutritious and are highly acceptable.

Cookies can be recommended in daily diet, for children and also prevent malnourish in children and adults. The consumers today are conscious of health and demanding newer products which satiate both palate and health. 


\section{Acknowledgement}

I sincerely thank to my institute staff for the invaluable guidance and encouragement given to me throughout my research work. I owe my thanks to my family and friends for their cooperation and encouragement during the research work.

\section{References}

Anonymous, 1990, Official Methods of Analysis, Association of Official Analytical Chemists, $20^{\text {th }}$ edition, Washington, DC. Pp. 570.

Asp, N.G., Johansson, C. G., Halmer, H. and Siljestorm, M, 1983, Rapid enzymatic assay of insoluble dietary fiber. $J$. Agric. Food Chem., 31: 476-482.

Ballolli, U., 2010, Development and value addition to barnyard millet (Echinochloa frumantacea) cookies. M. Sc. Thesis, Univ. Agric. Sci., Dharwad (India).

Hemalatha, G., Amutha, S., Vivekanadan, P. and Rajanna, G., 2006, Development of little millet (Panicum sumatrense) substituted biscuits and characterization of packaging requirements. Tropical Agric. Res., 18:43-52.

Mridula, D. and Gupta, R. K., 2008, Effect of bajra flour on quality of biscuits fortified with defatted soy flour. The Ind. J. Nutr. Dietet., 45: 17-25.

Munck, L., 1995, New milling technologies and products; whole plant utilization by milling and separation of the botanical and chemical components. In: Dendy, D. A. V. (Ed), Sorghum and Millets; Chemistry and Technology, American Association of Cereal Chemists St. Paul, MN, USA, pp. 223-281.

Pai, J. S., 2006, Traditional Indian Foods: Physico-Chemical Aspects Inc: Nutritional Health Benefits of millets, PFNDAI, edited Mr. Badami M. C. Dr. Holla K. S. Dr. Padgaonkar S. V. Mr. Sakhavalkar J. A. Ms. Swati Deodhar Singh, Applied Science Publisher, Edinburgh, p. 3

Shrivastav, P., Verma, A. K., Walia, R., Parveen, R. and Singh, A. K., 2016, Jaggery: a Revolution in the Field of Natural Sweeteners. European $J$. Pharmaceut. Med. Res., 3(3): 198-202.

Venkatasubramanian, C., 2011, Nutritional quality and acceptability of organic and conventional foods. Indian J. Sci. Technol., 4(3): 0974-6846.

Walter, R. J., 2012, Health effects of noncentrifugal sugar (NCS): A Review. Sugar Tech., 14(2):87-94.

\section{How to cite this article:}

Mahalaxmi, B.K. and Hemalatha, S. 2019. Functional and Nutritional Characteristics of Organic Jaggery Millet Cookies. Int.J.Curr.Microbiol.App.Sci. 8(07): 2772-2782. doi: https://doi.org/10.20546/ijcmas.2019.807.346 